\title{
Vascularized Lymph Node Transfer
}

National Cancer Institute

\section{Source}

National Cancer Institute. Vascularized Lymph Node Transfer. NCI Thesaurus. Code C160770.

A surgical treatment for lymphedema. This involves the microsurgical transfer of lymph node-containing tissue to a lymphedematous limb, which works based on the movement of lymphatic fluid from the affected limb into the transferred lymph node and drainage via the newly anastomosed venous route. 